\title{
Impacts of prescribed burning on soil greenhouse gas fluxes in a suburban native forest of south-eastern Queensland, Australia
}

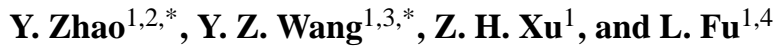 \\ ${ }^{1}$ Environmental Futures Research Institute and School of Natural Sciences, Griffith University, Nathan, Brisbane, \\ Queensland 4111, Australia \\ ${ }^{2}$ Institute of Geographical Sciences and Natural Resources Research, Chinese Academy of Sciences, Beijing 100101, China \\ ${ }^{3}$ Key Laboratory of Pollution Processes and Environmental Criteria, College of Environmental Science and Engineering, \\ Nankai University, Tianjin 300071, China \\ ${ }^{4}$ Key Laboratory of Digital Earth Science, Institute of Remote Sensing and Digital Earth, Chinese Academy of Sciences, \\ Beijing 100101, China \\ *These authors contributed equally to this work.
}

Correspondence to: Z. H. Xu (zhihong.xu@griffith.edu.au)

Received: 15 June 2015 - Published in Biogeosciences Discuss.: 9 July 2015

Accepted: 14 October 2015 - Published: 3 November 2015

\begin{abstract}
Prescribed burning is a forest management practice that is widely used in Australia to reduce the risk of damaging wildfires. Prescribed burning can affect both carbon (C) and nitrogen (N) cycling in the forest and thereby influence the soil-atmosphere exchange of major greenhouse gases, i.e. carbon dioxide $\left(\mathrm{CO}_{2}\right)$, methane $\left(\mathrm{CH}_{4}\right)$ and nitrous oxide $\left(\mathrm{N}_{2} \mathrm{O}\right)$. To quantify the impact of a prescribed burning (conducted on 27 May 2014) on greenhouse gas exchange and the potential controlling mechanisms, we carried out a series of field measurements before (August 2013) and after (August 2014 and November 2014) the fire. Gas exchange rates were determined in four replicate plots which were burned during the combustion and in another four adjacent unburned plots located in green islands, using a set of static chambers. Surface soil properties including temperature, $\mathrm{pH}$, moisture, soil $\mathrm{C}$ and $\mathrm{N}$ pools were also determined either by in situ measurement or by analysing surface $10 \mathrm{~cm}$ soil samples. All of the chamber measurements indicated a net sink of atmospheric $\mathrm{CH}_{4}$, with mean $\mathrm{CH}_{4}$ uptake ranging from 1.15 to $1.99 \mathrm{mg} \mathrm{m}^{-2} \mathrm{~d}^{-1}$. Prescribed burning significantly enhanced $\mathrm{CH}_{4}$ uptake as indicated by the significant higher $\mathrm{CH}_{4}$ uptake rates in the burned plots measured in August 2014. In the following 3 months, the $\mathrm{CH}_{4}$ uptake rate was recovered to the pre-burning level. Mean $\mathrm{CO}_{2}$ emission from the forest soils ranged from 2721.76 to $7113.49 \mathrm{mg} \mathrm{m}^{-2} \mathrm{~d}^{-1}$. The effect of prescribed burning on
\end{abstract}

$\mathrm{CO}_{2}$ emission was limited within the first 3 months, as no significant difference was observed between the burned and the adjacent unburned plots in both August and November 2014. The $\mathrm{CO}_{2}$ emissions showed more seasonal variations, rather than the effects of prescribed burning. The $\mathrm{N}_{2} \mathrm{O}$ emission in the plots was quite low, and no significant impact of prescribed burning was observed. The changes in understory plants and litter layers, surface soil temperature, $\mathrm{C}$ and $\mathrm{N}$ substrate availability and microbial activities, following the prescribed burning, were the factors that controlled the greenhouse gas exchanges. Our results suggested that the low-intensity prescribed burning would decrease soil $\mathrm{CO}_{2}$ emission and increase $\mathrm{CH}_{4}$ uptake, but this effect would be present within a relatively short period. Only slight changes in the surface soil properties during the combustion and very limited impacts of prescribed burning on the mineral soils supported the rapid recovery of the greenhouse gas exchange rates.

\section{Introduction}

As a result of continuously increasing greenhouse gas emissions, global climate change studies have predicted a drier future with a high probability of increasing temperatures, lower average rainfall and an increase in the frequency and 
severity of droughts and extreme weather events (Sherwood and Fu, 2014; Fu et al., 2015). In Australia, climate changes were also identified as key drivers of the increases in days with high fire risk weather and probability of severe wildfires (Murphy and Timbal, 2008; Fest, 2013). In response to these predictions, the use of prescribed burning is increased in Australia forest management to protect both native and plantation forests from the risk of damaging wildfires (Wang et al., 2014). Prescribed burns are generally targeted at the understorey vegetation and surface litters, while aiming for minimum damage to overstorey trees. Despite the controlled burning conditions, prescribed burning can still have significant effects on soil water content and soil temperature. The combustion event would also result in amounts of charcoal and dying tree roots (Kim et al., 2011; Sullivan et al., 2011) and therefore alter root activities, organic matter decomposition, availability of substrate and soil $\mathrm{N}$ dynamics (Weber, 1990; Certini, 2005; Livesley et al., 2011; Wang et al., 2014). All these parameters are closely related to three major greenhouse gas exchanges at soil-atmosphere interface, namely carbon dioxide $\left(\mathrm{CO}_{2}\right)$, methane $\left(\mathrm{CH}_{4}\right)$ and nitrous oxide $\left(\mathrm{N}_{2} \mathrm{O}\right)$. Studies have paid special attention to these greenhouse gas fluxes, not only because of the warming effect caused by $\mathrm{CO}_{2}, \mathrm{CH}_{4}$ and $\mathrm{N}_{2} \mathrm{O}$ in the atmosphere globally (Sherwood and $\mathrm{Fu}, 2014$ ), but also because of their use as very effective indicators for evaluating soil $\mathrm{C}$ and $\mathrm{N}$ pools and soil microbial activities (Weber, 1990). Many studies have been conducted to quantify $\mathrm{CO}_{2}, \mathrm{CH}_{4}$ and $\mathrm{N}_{2} \mathrm{O}$ exchanges at forest soil-atmosphere interface and the impact of intensive wildfires in different climate regions, but very few works have reported the effects of prescribed burning on soil greenhouse gas emissions, especially in Australia.

$\mathrm{CO}_{2}$ is the primary greenhouse gas and accounts for a major part of anticipated global warming (Sommerfeld et al., 1993). Within the forest ecosystem, soil is the major C reservoir while soil respiration is an important mechanism that releases the fixed $\mathrm{C}$ into the atmosphere (Seidl et al., 2014). Forest fires are generally reported to decrease soil $\mathrm{CO}_{2}$ efflux (Weber, 1990; Burke et al., 1997; Kim et al., 2011; Livesley et al., 2011). The key driving factors of fires on $\mathrm{CO}_{2}$ efflux are the changes in soil temperature, moisture and fine root activities. As the altered temperature and moisture could change the amplitude of seasonal variations in $\mathrm{CO}_{2}$ emissions, reduced fine root activities after fires are more responsible for the decreased $\mathrm{CO}_{2}$ (Kim et al., 2011; Sullivan et al., 2011). Sullivan et al. (2011) also concluded that reduced microbial respiration indicated by microbial biomass after prescribed burning could further contribute to the decreased $\mathrm{CO}_{2}$ efflux. Unlike with this "decrease" effect, Fest et al. (2015) also reported that low-intensity burning slightly increased soil $\mathrm{CO}_{2}$ flux in temperature eucalypt forest systems. This is attributed to the higher inputs of easily decomposable compounds, higher surface temperature and soil nutrient depletion after burning treatments (Fest et al., 2015).
The $\mathrm{CH}_{4}$ is the second most important greenhouse gas, with a global warming potential of 25 times greater than $\mathrm{CO}_{2}$. Aerated forest soils are one of the most important biological sink of $\mathrm{CH}_{4}$ as the results of oxidation of atmospheric $\mathrm{CH}_{4}$ by methanotrophic bacteria. Studies have reported both positive (Livesley et al., 2011; Sullivan et al., 2011; Fest, 2013) and no significant impact of fires on forest soil $\mathrm{CH}_{4}$ uptake (Kim et al., 2011). Since soil gas diffusivity is one of the key regulators of soil $\mathrm{CH}_{4}$ uptake in the forest soil system, prescribed burning altered soil moisture condition, and removal of litter layer and soil $\mathrm{O}$ horizon would weaken or eliminate the barrier effect of the surface soil and thereby increase diffusion of $\mathrm{CH}_{4}$ into soil profile (Sullivan et al., 2011; Fest, 2013).

The $\mathrm{N}_{2} \mathrm{O}$ emission is less reported in forest soil studies, despite the greater climate warming potential of $\mathrm{N}_{2} \mathrm{O}$ than $\mathrm{CO}_{2}$ and $\mathrm{CH}_{4}$ and the large contribution of forest soil $\mathrm{N}_{2} \mathrm{O}$ emission to the global atmospheric $\mathrm{N}_{2} \mathrm{O}$ budget (Kiese and Butterbach-Bahl, 2002; Kiese et al., 2003). Fires would affect soil $\mathrm{N}_{2} \mathrm{O}$ emission by altering the rates of nitrification and denitrification processes but there are only few published studies and their results are inconsistent. Fires could change forest soil $\mathrm{N}$ storages but the mechanism of driving $\mathrm{N}_{2} \mathrm{O}$ emission changes is unclear (Certini, 2005; Nave et al., 2011). Available N substrate (Kiese et al., 2003), soil moisture and temperature (Fest et al., 2009), water filled pore space (Kiese and Butterbach-Bahl, 2002) and stand conditions (Butterbach-Bahl et al., 1997) are potential factors which could affect $\mathrm{N}_{2} \mathrm{O}$ emission rates.

The eucalypt-dominated natural forest ecosystem studied in this experiment is quite typical across most of Australia's forest areas, with a total of 92 million hectares or $74 \%$ of Australia's forest area (Department of Agriculture, http://www.agriculture.gov.au/abares/ forestsaustralia/profiles/eucalypt-forest). These forests hold important $\mathrm{C}$ storage over the country and also provide important ecosystem services such as biodiversity, recreation, water resource and wood products (Fest et al., 2009). Prescribed burning is one of the most important management tools in Australia to protect these forests from fires and maintain their functions, including forest regeneration, site preparation, fuel reduction and habitat management (Guinto et al., 2000; Bai et al., 2012; Wang et al., 2014). Some studies have reported the greenhouse gas emissions from Australian forest soils (Kiese and Butterbach-Bahl, 2002; Dalal et al., 2003), but the impact of prescribed burning on Australian eucalyptus forests are rarely studied. Therefore, we have limited understanding about the magnitude and direction of the effect of prescribed burning on the greenhouse gas exchange which is critical to understand the interaction between burned ecosystem and the atmosphere. In this study, we setup four sampling plots which had similar stand conditions to address the following questions: (1) would prescribed burning affect greenhouse gas emissions at the soil atmosphere interface? (2) How long would these effects last? And (3) what would be 
the controlling factors? To address these questions, we conducted a series of field measurements of $\mathrm{CH}_{4}, \mathrm{CO}_{2}$ and $\mathrm{N}_{2} \mathrm{O}$ exchange at surface soil before and after prescribed burning. To examine the potential driving factors and mechanisms we also collected surface soil samples for analysing biological, chemical and physical variables which might be altered by prescribed burning.

\section{Methods}

\subsection{Site description}

The study was carried out in Toohey Forest $\left(27^{\circ} 30^{\prime \prime} \mathrm{S}\right.$, $\left.135^{\circ} 02^{\prime \prime} \mathrm{E}\right)$, located $10 \mathrm{~km}$ south of Brisbane in south-eastern Queensland, Australia (Fig. 1). This forest accounts for about 600 hectares dominated by different species of eucalypt and contains some 460 species of vascular plants. About half of this forest is a local government conservation reserve and surrounded by suburban areas (Catterall and Wallace, 1987; Catterall et al., 2001; Farmer et al., 2004). The climate for the region and around it is characterised as subtropical with a dominant weather pattern of hot, wet summers and cool, dry winters. The mean annual rainfall is about $1000 \mathrm{~mm}$, with the majority received during summer months. Temperatures generally ranged between approximately 30 and $35^{\circ} \mathrm{C}$ in summer and 10 and $15^{\circ} \mathrm{C}$ in winter.

Patterns of burning prior to the 1950s are unknown, but from the 1950s to the early 1970s, individual fires probably burned across a large proportion of the area. From the early 1970s individual fires were confined to more localised areas and created a spatially heterogeneous fire regime. Since 1993, 27 blocks within Toohey Forest have been conducted with regular prescribed burnings (Wang et al., 2015). Prescribed burnings are generally low-intensity cool burns, and usually occur at the end of the dry season in winter. Generally, every burning event would last for several hours (usually overnight) from the ignition to extinguishing of any small fires. The fire was monitored and controlled during the burning.

The prescribed burning of this study was conducted on 27 May 2014. Last recorded burning in this block was on 18 June 1999. Before the prescribed burning, we selected four plots (around $30 \mathrm{~m}$ between each other, Fig. 1) with similar stand conditions for sampling. The understory of these plots was burned out during the recent prescribed burning, which left a layer of wood charcoal on the ground. After the burning, these four plots were measured repeatedly at 3 months (August 2014) and 6 months (November 2014). Detailed sampling dates and weather conditions for the selected sampling events were listed in Table 1. Briefly, the sampling events were conducted under clear weather conditions and there were no major precipitation events either 30 days or 90 days before the sampling events. Furthermore, another four unburned plots adjacent to the burned plots as paired plots were selected to further examine the impacts of prescribed burning. These unburned plots were located in the adjacent green islands of those not touched by the recent prescribed burning.

\subsection{Sampling method}

As previously described, four plots were selected for sampling. We treated these four plots as replicates and a series of experiments, including impacts of burning on soil greenhouse gas emission, $\mathrm{N}$ transformation and litter decomposition, were carried out in each plot, a total of 11 chambers (rings) were established for specific purposes through introducing different treatments (e.g. water or solution application, $\mathrm{N}$ isotope enrichment), only the chamber for soil gas sampling was left untreated and the results were presented here.

We adopted a static chamber method to measure $\mathrm{CO}_{2}, \mathrm{CH}_{4}$ and $\mathrm{N}_{2} \mathrm{O}$ emissions simultaneously. A PVC chamber (cylinder with a diameter of $245 \mathrm{~mm}$, wall thickness approximately $4 \mathrm{~mm}$ and length $300 \mathrm{~mm}$ ) was installed in each of the four plots. The chambers were sharpened at the bottom edge and were pushed $10 \mathrm{~cm}$ into the soil using a hammer. Weed control was performed within and around the chamber to prevent the impact of metabolic activities grasses. Sampling was conducted a week later after the chambers were set. Gas fluxes across the soil-atmosphere interface were determined daily by sampling air in the headspace of PVC chambers during the 4-day field measurement. The internal volume of a chamber was $9.4 \mathrm{~L}$ when placed $10 \mathrm{~cm}$ deep into forest floor. There were four holes evenly distributed on the chamber $(10 \mathrm{~cm}$ above ground) to help the inner atmosphere fully mixed with outside, on all sampling occasions prior to each gas sampling, these holes were sealed with a set of rubber plugs. The top of the chamber was also covered with a cap fastened with a black rubber band to prevent any gas exchange between the inner headspace and the outside. After covering the cap, $15 \mathrm{~mL}$ gas samples were taken from the sampling port at the centre of the chamber top at 0 and $60 \mathrm{~min}$ after chamber deployment. A $25 \mathrm{~mL}$ syringe was attached to the sampling port and the plunger of the syringe was pumped up and down several times to mix the gases in the chamber before taking a sample. Gas samples were immediately injected into pre-evacuated $15 \mathrm{~mL}$ tubes capped with butyl rubber stoppers and prepared for analysis of $\mathrm{CO}_{2}, \mathrm{CH}_{4}$ and $\mathrm{N}_{2} \mathrm{O}$. Gas sampling was conducted for 4 consecutive days to capture consistent emission patterns from the 4 plots and the data were pooled for statistical analysis (Lennon, 2011).

All gas samplings were conducted during daylight hours from approximately 08:00 to 12:00 (GMT +10$)$. However, considering the great spatial heterogeneity of soil gas fluxes reported by existing studies (Kim et al., 2011; Sullivan et al., 2011), the acquired results in the present study might be tangled with burning-induced impacts and spatially related variabilities due to the relative large distance among the 


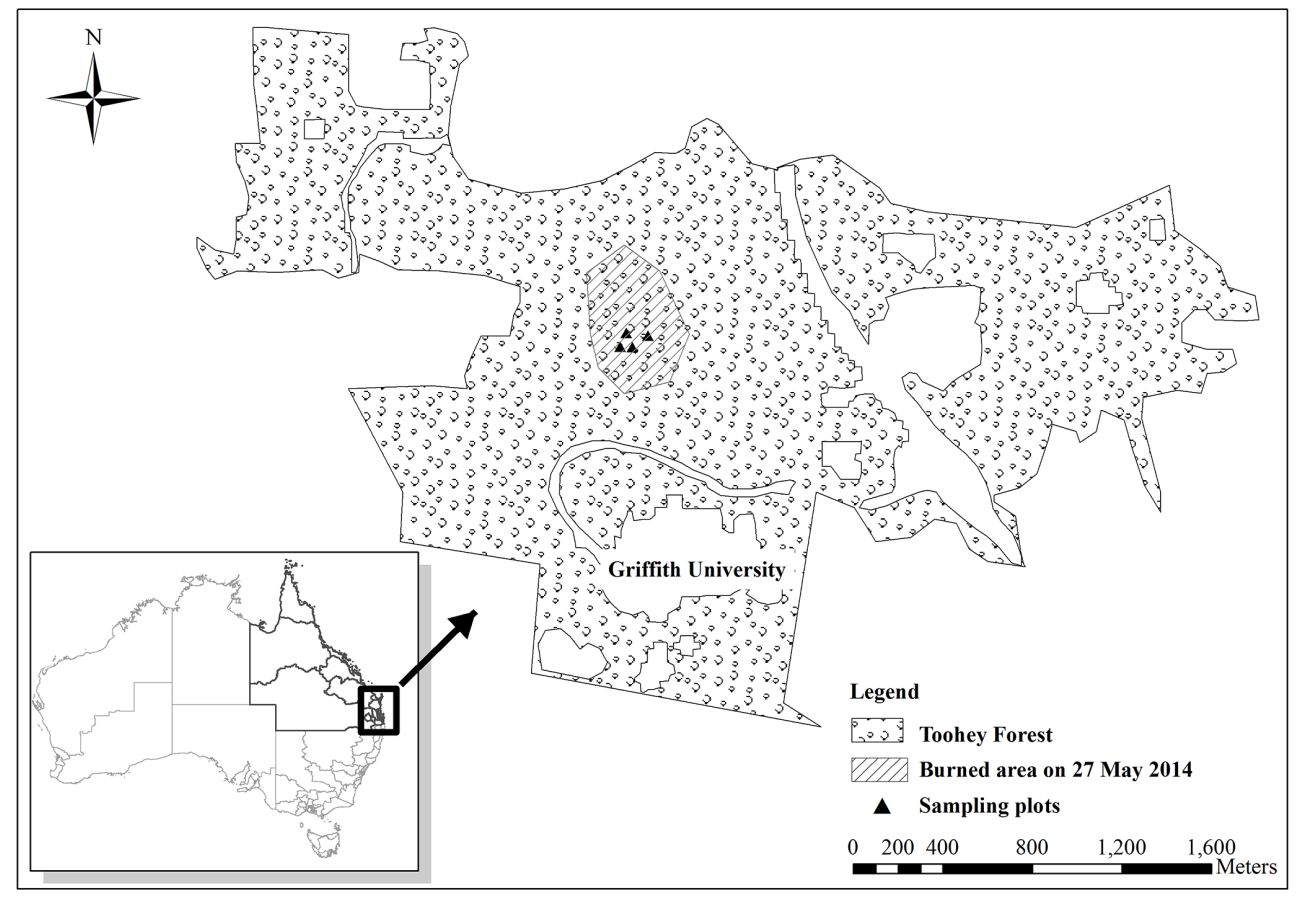

Figure 1. Map of the study site in Toohey Forest located in south-eastern Queensland, Australia.

Table 1. Weather conditions for the three sampling events, precipitation was recorded by the $M_{\mathrm{t}}$ Gravatt Alert weather station $\left(27.55^{\circ} \mathrm{S}\right.$, $153.07^{\circ} \mathrm{E}, \sim 2 \mathrm{~km}$ from the sampling plots) and the data were collected at the website of Bureau of Meteorology (http://www.bom.gov.au).

\begin{tabular}{lrrrrr}
\hline $\begin{array}{l}\text { Sampling } \\
\text { events }\end{array}$ & $\begin{array}{r}\text { Sampling } \\
\text { dates }\end{array}$ & $\begin{array}{r}\text { Antecedent } \\
\text { precipitation }^{\mathrm{a}} \\
(30 \text { days, mm })\end{array}$ & $\begin{array}{r}\text { Antecedent } \\
\text { precipitation } \\
(3 \text { months, mm })\end{array}$ & $\begin{array}{r}\text { Rainfall during } \\
\text { sampling } \\
\text { period }\end{array}$ & $\begin{array}{r}\text { Temperature } \\
\text { measured } \\
\text { on-site }\end{array}$ \\
\hline Aug 2013 & $27-30$ & 4 & 71 & 0 & 24.76 \\
Aug 2014 & $5-8$ & $10^{\mathrm{b}}$ & 22 & 0 & 23 \\
Nov 2014 & $10-13$ & 11 & $85^{\mathrm{c}}$ & 0 & 29.88 \\
\hline
\end{tabular}

${ }^{\mathrm{a}}$ Total rainfall for the indicated periods, ${ }^{\mathrm{b}}$ highest daily rainfall was $7 \mathrm{~mm}$ recorded on $27 \mathrm{July} 2014,{ }^{\mathrm{c}}$ most rainfall for this period was recorded on 17 August 2014 (69 mm).

plots (Prosser, 2010). We considered the similarity of soil and stand conditions (eucalypt forest with moderate density) and plot location (middle slope) when selecting the plots, which would partly offset this potential impact.

\subsection{Soil property analysis}

The top $10 \mathrm{~cm}$ of soil in the chamber was collected with a shovel. Collected soil samples were thoroughly mixed and passed through a $2 \mathrm{~mm}$ sieve. Soil moisture was measured gravimetrically after drying at $105^{\circ}$ for $48 \mathrm{~h}$. $\mathrm{pH}$ was measured with a 1:5 aqueous solution after shaking for $30 \mathrm{~min}$. Soil inorganic $\mathrm{N}$ concentrations were extracted with $2 \mathrm{M} \mathrm{KCL}$ and measured using a modified micro-diffusion method (Wang et al., 2015) and a Discrete Chemistry Analyser (Westco Smartchem SC 200, Discrete Wet Chemistry Analyser).
To determine water soluble organic C (WSOC) and total $\mathrm{N}$ (WSTN), $7 \mathrm{~g}$ fresh soil was added to $35 \mathrm{~mL}$ distilled water in a $50 \mathrm{~mL}$ plastic centrifuge vial, the suspension was then shaken by an end-over-end shaker for 5 min followed by centrifuging at $10000 \mathrm{rpm}$ for $10 \mathrm{~min}$. The suspension was then filtered through a Whatman 42 filter paper and a $33 \mathrm{~mm}$ Millex syringe-driven $0.45 \mu \mathrm{m}$ filter successively before being analysed with a Shimadzu TOC-VCSH/CSN TOC/N analyser. Similarly, hot water extractable organic C (HWEOC) and total N (HWETN) were also measured, while the only difference was $1: 5$ soil water solution, was incubated in a capped and sealed tube at $70^{\circ} \mathrm{C}$ for $18 \mathrm{~h}$.

Soil microbial biomass C (MBC) and N (MBN) were determined using the fumigation-extraction method described by Vance et al. (1987) and Brookes et al. (1985). Briefly, fumigated and non-fumigated soils (5 $\mathrm{g}$ dry weight equivalent) were extracted with $25 \mathrm{~mL}$ of $0.5 \mathrm{M} \mathrm{K}_{2} \mathrm{SO}_{4}$ (soil/extractant 
ratio $1: 5)$. The fumigation lasted for $16 \mathrm{~h}$. Samples were shaken for $30 \mathrm{~min}$ and then filtered through a Whatman 42 filter paper. Soluble organic C and total soluble N (TSN) in the fumigated and non-fumigated samples were determined using a Shimadzu TOC-VCSH/CSN TOC/N analyser. MBC and $\mathrm{MBN}$ were calculated using conversion factors of 2.64 and 2.22 for C (Vance et al., 1987) and N (Brookes et al., 1985), respectively.

\subsection{Gas analysis}

Collected gas samples were sent to laboratory for gas chromatography (GC) analysis for $\mathrm{CO}_{2}, \mathrm{CH}_{4}$ and $\mathrm{N}_{2} \mathrm{O}$ concentrations shortly after the field sampling. The concentrations of $\mathrm{CO}_{2}$ and $\mathrm{CH}_{4}$ were measured using a $\mathrm{GC}$ system (GC2010 PLUS Shimadzu) with flame ionisation detector and $\mathrm{N}_{2} \mathrm{O}$ was measured using the same GC system with Electron Capture Detector. The standards $\left(0.5\right.$ for $\mathrm{CH}_{4}, 400.5$ for $\mathrm{CO}_{2}$ and $0.3 \mathrm{ppm}$ for $\mathrm{N}_{2} \mathrm{O}$ ) were run before and after each set of samples to ensure the reproducibility of measurements. Gas fluxes for $\mathrm{CO}_{2}, \mathrm{CH}_{4}$ and $\mathrm{N}_{2} \mathrm{O}$ were determined from a regression analysis with gas concentration change within the chamber versus time.

\subsection{Statistical analysis}

All statistical analyses were performed using IBM SPSS STATISTICS (version 20) software. One-way ANOVA was introduced to examine statistically significant differences between soil gas fluxes measured before and after the burning in the burned plots. This analysis was also applied to compare the fluxes between burned and unburned plots in $\mathrm{Au}-$ gust 2014 and November 2014, respectively. Collected soil properties and gas fluxes at the four replicate plots during the three sampling events were also pooled together for Pearson correlation analysis to detect possible effects of soil environmental variables on soil $\mathrm{CO}_{2}, \mathrm{CH}_{4}$ and $\mathrm{N}_{2} \mathrm{O}$ fluxes.

\section{Results}

\subsection{Greenhouse gas exchange rates before and after prescribed burning}

Average $\mathrm{CH}_{4}, \mathrm{CO}_{2}$ and $\mathrm{N}_{2} \mathrm{O}$ emissions rates of the four replicate plots for each sampling event were listed in Table 2. While temporal patterns of gas exchange for the 4-day sampling of the three sampling periods were shown in Fig. 2. Coefficient of variance ( $\mathrm{CV}$, ratio of the standard deviation to the mean) among the plots during the 4 sampling days ranged from 14-68\% (mean 32\%), 9-15\% (mean 10\%) and 10-28\% (mean 16\%), for August 2013, August 2014 and November 2014, respectively. All the sampling plots showed negative $\mathrm{CH}_{4}$ emission rates during the three sampling events, or an uptake in atmospheric $\mathrm{CH}_{4}$. In the burned plots, mean $\mathrm{CH}_{4}$ uptake was significantly increased by $64 \%$
3 months after the prescribed burning ( $p<0.001$ ), while during the third sampling period, $\mathrm{CH}_{4}$ uptake rate became similar to that before the burning ( $p=0.843)$. In the unburned plots, $\mathrm{CH}_{4}$ uptake was relatively stable during the dates of the sampling periods and also showed less variation between $\mathrm{Au}$ gust 2014 and November 2014. The significant difference in mean $\mathrm{CH}_{4}$ uptake rate in August $2014(p<0.001)$ but similar rates in November $2014(p=0.921)$ also confirmed that the $\mathrm{CH}_{4}$ uptake increased at the first 3 months but was recovered to the pre-burning level about 6 months after prescribed burning.

Soil $\mathrm{CO}_{2}$ flux showed relative higher variance as indicated by the higher standard deviations (Fig. 2) and CVs (ranged from 43 to $50 \%$ during the three sampling periods). Mean $\mathrm{CO}_{2}$ emission from all burned plots was significantly decreased by $41 \%$ in August 2014 ( $p<0.001)$. In November 2014, $\mathrm{CO}_{2}$ efflux rates had exceeded that before the burning by $28 \%$ but the difference was not significant $(p=0.392)$. Similar $\mathrm{CO}_{2}$ emission rates between the burned and adjacent unburned plots during the sampling dates of August $2014(p=0.549)$ and November $2014(p=0.218)$ were also observed. This might indicate that the temporal dynamics detected at the burned plots reflected more natural variations rather than burning-induced impacts.

The lower $\mathrm{N}_{2} \mathrm{O}$ emission rates, compared to that in August 2013, were found both in August $2014(p=0.003)$ and November 2014 ( $p<0.001)$. During the three sampling periods, the study plots were not solely performed as a source of atmospheric $\mathrm{N}_{2} \mathrm{O}$, on 27 August 2013, 6 August 2014 and most days of November 2014, but the plots also took up $\mathrm{N}_{2} \mathrm{O}$ from the atmosphere. No significant difference in $\mathrm{N}_{2} \mathrm{O}$ emission was observed between the burned and unburned plots in both August and November 2014.

\subsection{Soil basic properties and their relationships with gas exchange rates}

After the prescribed burning, soil moisture showed no significant difference between burned and unburned plots ( $p=0.804$ ), although most of the sampling plots (five out of eight for the two sampling events in 2014) had relative higher values. Soil temperature was slightly higher for most sampling dates in the burned plots, but no significant difference was found in August 2014 ( $p=0.644)$ and November 2014 $(p=0.751)$. The $\mathrm{pH}$ in the surface soil was higher in 2014 than in 2013, and the values in all burned plots were slightly higher than those of unburned sites $(p=0.293) . \mathrm{NO}_{3}-\mathrm{N}$ was quite low both before and after the prescribed burning, but $\mathrm{NH}_{4}-\mathrm{N}$ was significantly increased after the prescribed burning (Table 3).

When relating these soil parameters to greenhouse gas emissions from the soil surface, soil temperature showed a positive correlation with the $\mathrm{CH}_{4}$ uptake $(R=0.232$, $p=0.044)$ and $\mathrm{CO}_{2}$ efflux $(R=0.47, p<0.000)$ and a negative correlation with $\mathrm{N}_{2} \mathrm{O}$ emission $(R=-0.284$, 

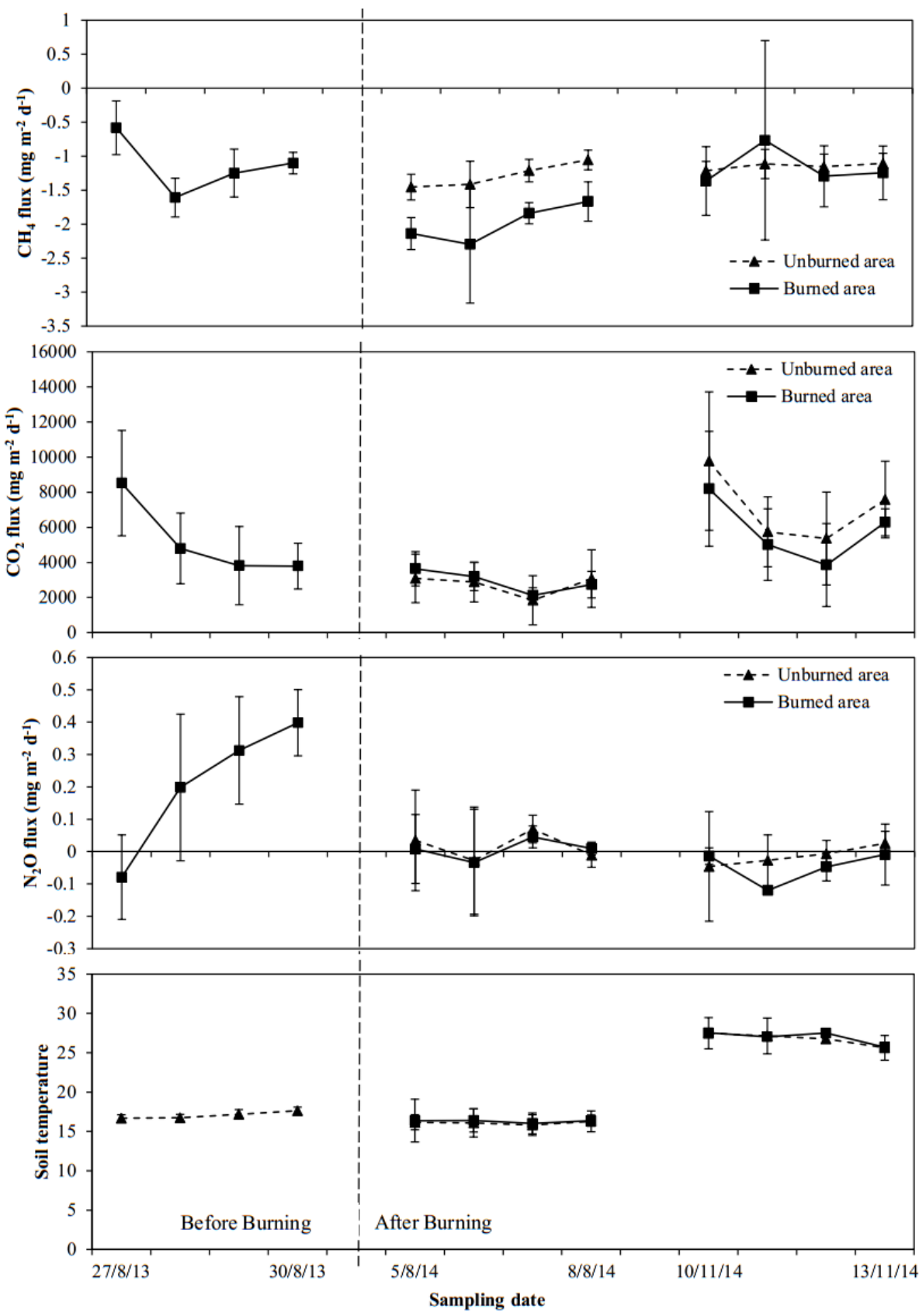

Figure 2. $\mathrm{CH}_{4}, \mathrm{CO}_{2}$ and $\mathrm{N}_{2} \mathrm{O}$ exchange rates and on-site measured soil temperature before and after the prescribed burning. The dash line indicated the date of burning conducted on 27 May 2014. Each sampling period lasted for 4 days and the values were averaged from the 4 selected plots each day. The vertical bars indicated the standard error of the mean.

$p=0.011) . \mathrm{pH}$ was negatively correlated with the $\mathrm{CH}_{4}$ uptake $(R=-0.595, p=0.006)$ and $\mathrm{CO}_{2}(R=-0.591$, $p=0.006)$ emission. $\mathrm{NH}_{4}-\mathrm{N}$ was negatively correlated with $\mathrm{N}_{2} \mathrm{O}$ emission $(R=-0.533, p=0.015)$.

\subsection{Soil $\mathrm{C}$ and $\mathrm{N}$ dynamics before and after burning}

There was no significant difference in WSOC in the burned plots between August 2013 and August 2014, and only slightly decreased WSOC was observed in August 2014 (Table 3). However, WSOC was significantly higher in November $2014(p=0.034)$. No significant difference was found between any sampling periods for WSTN, despite higher WSTN in some burned plots than those before the prescribed burning and in the unburned plots (Table 3). HWEOC was significantly increased in August 2014 than that in August $2013(p<0.001)$ and in November 2014 it was recov- 
Table 2. Average gas exchange rates from surface soil in Toohey Forest before and after the prescribed burning. Values in parentheses indicate standard errors for the four replicate plots of each sampling period. Significant differences between measurements before and after the burning in the burned plots presented in lowercase letters. Significant differences between burned and adjacent unburned plots presented in uppercase letters. Mean values followed by the same letter are not significantly different (one-way ANOVA, $p \geq 0.05$ ).

\begin{tabular}{|c|c|c|c|c|}
\hline Sites & Dates & $\begin{array}{l}\mathrm{CH}_{4} \\
\mathrm{mg} \mathrm{m}^{-2} \mathrm{~d}^{-1}\end{array}$ & $\begin{array}{l}\mathrm{CO}_{2} \\
\mathrm{mg} \mathrm{m}^{-2} \mathrm{~d}^{-1}\end{array}$ & $\begin{array}{l}\mathrm{N}_{2} \mathrm{O} \\
\mathrm{mg} \mathrm{m}^{-2} \mathrm{~d}^{-1}\end{array}$ \\
\hline \multirow[t]{3}{*}{ Burned } & Aug 2013 & $-1.21(0.42) \mathrm{a}$ & $5009.17(2657.67) \mathrm{a}$ & $0.21(0.24) \mathrm{a}$ \\
\hline & Aug 2014 & $-1.99(0.51) \mathrm{bA}$ & $2974.24(895.78) \mathrm{bA}$ & $0.00(0.10) \mathrm{aA}$ \\
\hline & Nov 2014 & $-1.17(0.78) \mathrm{aC}$ & 5835.69 (2639.99)aB & $-0.04(0.07) b B$ \\
\hline \multirow[t]{2}{*}{ Unburned } & Aug 2014 & $-1.28(0.26) \mathrm{B}$ & $2721.76(1360.24) \mathrm{A}$ & $0.02(0.11) \mathrm{A}$ \\
\hline & Nov 2014 & $-1.15(0.16) \mathrm{C}$ & 7113.49 (3086.07)B & $-0.01(0.09) \mathrm{B}$ \\
\hline
\end{tabular}

Table 3. Surface soil properties in Toohey Forest before and after the prescribed burning. Values in parentheses indicate standard errors for the four replicate plots of each sampling period. Soil moisture is presented in \%. Other parameters (except $\mathrm{pH})$ are presented in $\mathrm{mg} \mathrm{kg}^{-1}$.

\begin{tabular}{llrrrrrrrrrr}
\hline Sites & Date & Moisture & $\mathrm{pH}$ & $\mathrm{NH}_{4}-\mathrm{N}$ & $\mathrm{NO}_{3}-\mathrm{N}$ & WSOC & WSTN & HWEOC & HWETN & MBC & MBN \\
\hline Burned & Aug 2013 & 12.3 & 4.33 & 1.78 & 0.02 & 88.83 & 7.10 & 875.44 & 67.80 & 522.45 & 56.37 \\
& & $(4.4)$ & $(0.10)$ & $(0.55)$ & $(0.03)$ & $(13.54)$ & $(0.83)$ & $(180.32)$ & $(10.38)$ & $(76.18)$ & $(14.2)$ \\
& Aug 2014 & 10.3 & 5.76 & 6.76 & 0.09 & 80.00 & 6.81 & 2809.99 & 183.75 & 378.94 & 35.77 \\
& & $(2.7)$ & $(0.17)$ & $(2.30)$ & $(0.05)$ & $(20.20)$ & $(2.16)$ & $(479.18)$ & $(39.10)$ & $(103.58)$ & $(10.00)$ \\
& \multirow{2}{*}{ Nov 2014 } & 10.3 & 4.88 & 10.63 & 0.10 & 148.09 & 7.38 & 893.47 & 54.08 & 444.68 & 48.02 \\
& & $(3.0)$ & $(0.24)$ & $(4.18)$ & $(0.12)$ & $(38.25)$ & $(2.97)$ & $(310.29)$ & $(19.32)$ & $(45.27)$ & $(7.15)$ \\
\hline \multirow{2}{*}{ Unburned } & \multirow{2}{*}{ Aug 2014 } & 10.1 & 5.44 & 3.79 & 0.03 & 97.27 & 7.22 & 3638.29 & 203.91 & 493.62 & 45.26 \\
& & $(2.0)$ & $(0.24)$ & $(1.67)$ & $(0.04)$ & $(28.36)$ & $(1.19)$ & $(571.01)$ & $(17.70)$ & $(73.81)$ & $(8.19)$ \\
& \multirow{2}{*}{ Nov 2014 } & 9.8 & 4.67 & 6.44 & 0.04 & 114.35 & 5.14 & 942.56 & 51.94 & 406.07 & 42.76 \\
& & $(2.3)$ & $(0.16)$ & $(1.83)$ & $(0.07)$ & $(28.30)$ & $(1.29)$ & $(254.30)$ & $(13.02)$ & $(249.90)$ & $(14.56)$ \\
\hline
\end{tabular}

ered to the level before the prescribed burning $(p=0.929)$. The difference in HWEOC between the burned and adjacent unburned plots was also significant in August 2014 ( $p=0.0361$ ) but insignificant in November 2014. The situation was similar for HWETN.

MBC in the burned plots in August 2014 was $378.94 \mathrm{mg} \mathrm{kg}^{-1}$, which was lower than that in August 2013 (522.45 $\left.\mathrm{mg} \mathrm{kg}^{-1}, p=0.069\right)$, and this value did not change much in November 2014 (380.37 $\left.\mathrm{mg} \mathrm{kg}^{-1}\right)$.

The correlation analysis between soil $\mathrm{C}$ or $\mathrm{N}$ pools and gas emissions showed that $\mathrm{CH}_{4}$ uptake was negatively correlated with WSOC $(R=0.523, p=0.018)$. $\mathrm{CO}_{2}$ efflux had negative correlation with HWEOC $(R=-0.690, p=0.001)$ and HWETN $(R=-0.730, p<0.001) . \mathrm{N}_{2} \mathrm{O}$ emission was positively correlated with $\mathrm{MBN}(R=0.565, p=0.009)$.

\section{Discussions}

\subsection{Impacts of prescribed burning on soil properties}

Prescribed burning resulted in a slight increase in the surface soil temperature of this study, which is in agreement with most of the literature (Burke et al., 1997; Certini, 2005). The burning of the understory vegetation cover, together with the consumption of fuel loads, removal of litter layer and increased charred materials on the soil surface would all affect soil temperatures by intercepting direct sunlight and moderating the loss of soil heat by radiation. However, the controlled burning condition or low fire intensity limited this difference at an insignificant level. Meanwhile, the four selected plots in the study did not show consistent fluctuations in the surface soil moisture before and after the prescribed burning, which would generally be expected to decrease after a fire (Burke et al., 1997; Kim et al., 2011; Sullivan et al., 2011). Generally, increased soil temperature, combined with the reduced shade, would result in higher evaporation rates and therefore restrict the movement of water into soil profile (Burke et al., 1997; Certini, 2005). This might be attributed to the representativeness of the measurements and one measurement for each sampling period might not be adequate to represent the physical state of water in the soil (Weber, 1990).

An increase in soil $\mathrm{pH}$ values was found in the burned plots in August 2014 and it was returned to a similar level in November 2014. Although no significant difference was found between the burned and adjacent unburned plots in 2014, $\mathrm{pH}$ values for the burned plots were still higher than those at the unburned plots. The increased $\mathrm{pH}$ after the prescribed burning would be probably due to the release of ex- 
tractable basic cations from the deposited ashes during the burning. Several studies also reported increased $\mathrm{pH}$ after the fire (Guinto et al., 1999; Certini, 2005; Kim et al., 2011; Xue et al., 2014) and the increased $\mathrm{pH}$ would either be recovered to the pre-burning level within a year (Rhoades et al., 2004; Xue et al., 2014) or last for longer periods (Arocena and Opio, 2003; Ponder Jr. et al., 2009; Granged et al., 2011), depending on the site condition and burning intensities.

$\mathrm{NH}_{4}-\mathrm{N}$ was significantly increased after the prescribed burning, but no significant changes were observed for $\mathrm{NO}_{3}$ $\mathrm{N}$, since $\mathrm{NH}_{4}-\mathrm{N}$ was a direct product of combustion and $\mathrm{NO}_{3}^{-}$was formed from $\mathrm{NH}_{4}^{+}$some weeks or months later as a result of nitrification (Covington and Sackett, 1992; DiazRaviña et al., 1992; Wang et al., 2015). Hence, the increase in $\mathrm{NH}_{4}-\mathrm{N}$ was probably due to the transformation of organic $\mathrm{N}$ during the combustion. Also the deposition of organic $\mathrm{N}$ in ash and enhanced ammonification would also contribute to the increased $\mathrm{NH}_{4}^{+}$(Knoepp and Swank, 1993; Wan et al., 2001). This was also supported by the similar findings of Nardoto and Bustamante (2003) in savannas of Central Brazil and Covington and Sackett (1992) in a ponderosa pine forest in the USA.

The prescribed burning significantly reduced MBC in the surface soil and it showed no apparent sign of recovery 6 months after the prescribed burning. Decreased MBC after prescribed burning or wildfires have been reported and it would normally last for several years (Prieto-Fernández et al., 1998). As for the other two soil liable organic C pool indicators, WSOC showed no significant change before and after burning while HWEOC was significantly increased in August 2014 and returned to the pre-burning level in November 2014. While the low intensity of prescribed burning may only cause volatilisation of organic $\mathrm{C}$ to a limited extent, soil microbes might be decreased due to their sensitiveness to temperature (Hernández et al., 1997; Neary et al., 1999). This microbial lysis, as well as the heat-induced alterations of soil organic matter, contributed to the release of carbohydrates which were reflected by the initial increase in HWEOC.

\subsection{Variations in greenhouse gas exchanges and their driving factors}

\subsection{1 $\mathrm{CH}_{4}$ uptake}

The $\mathrm{CH}_{4}$ uptake rates before prescribed burning and 6 months after the burning from the burned plots and all fluxes from the unburned plots fall in the range of $\mathrm{CH}_{4}$ fluxes reported by Kiese et al. (2003) (from $0.84-1.63 \mathrm{mg} \mathrm{m}^{-2} \mathrm{~d}^{-1}$ ) and a recent study by Rowlings et al. (2012) which were conducted in a similar forest ecosystem in Australia. While the high uptake rate of $\mathrm{CH}_{4} 3$ months after the burning was also comparable to the results obtained in Australia forests under extreme dry conditions (Fest et al., 2009; Rowlings et al., 2012). The prescribed burning increased $\mathrm{CH}_{4}$ uptake in this study. The same effect has also been reported by Burke et al. (1997) and Sullivan et al. (2011). However, unlike most studies reporting that the enhanced $\mathrm{CH}_{4}$ uptake may last for several years, our results indicated that $\mathrm{CH}_{4}$ uptake rate was returned to the pre-burning level within 6 months after the prescribed burning. We obtained this conclusion from the similar $\mathrm{CH}_{4}$ uptake rates in November 2014 when compared to the $\mathrm{CH}_{4}$ uptake in the unburned plots and the rates before the burning in the burned plots. The low fire intensity of the prescribed burning in this study might cause less impact on the system and therefore shorten the required time to recover to the pre-burning conditions. Studies have found that fire intensity has a significant effect on forest soil $\mathrm{CH}_{4}$ consumption and $\mathrm{CO}_{2}$ emissions while severe wildfires always impact gas exchange rates for the subsequent several years (Burke et al., 1997; Neary et al., 1999; Sullivan et al., 2011). Kim et al. (2011) also found a quick recovery of $\mathrm{CH}_{4}$ uptake after 2 years of low-intensity burnings in a Japanese forest.

Soil moisture has been shown to be a key parameter controlling $\mathrm{CH}_{4}$ consumption by the soils through limiting the transport of atmospheric $\mathrm{CH}_{4}$ to microbial communities living at depth in the soil (Burke et al., 1997). However, we observed no significant relationships between soil moisture and $\mathrm{CH}_{4}$ uptake as reported by other studies (Sommerfeld et al., 1993; Kiese et al., 2003; Livesley et al., 2011). This was probably due to the low-intensity burning, and hence the prescribed burning did not affect soil water conditions in the soil horizons relevant to the $\mathrm{CH}_{4}$ oxidation, or the soil moisture was partly recovered to the pre-burning level. Castro et al. (1994) found that moisture control was strongest when between 60 and $100 \%$ of available soil pore space was filled with water. Meanwhile, surface soil temperature appeared to show more significant influence on $\mathrm{CH}_{4}$ uptake in this study. We also found a weak but significant relationship between $\mathrm{CH}_{4}$ uptake and soil $\mathrm{pH}$. The mechanism of how increased $\mathrm{pH}$ would affect soil $\mathrm{CH}_{4}$ uptake after fire is not clear, and Jaatinen et al. (2004) estimated that the increased $\mathrm{pH}$ after fire did not cause any change in the methanotroph community and would not be directly responsible for the increased uptake rates. Therefore, the increased $\mathrm{pH}$ in our study would probably indirectly affect $\mathrm{CH}_{4}$ uptake together with other fire introduced changes.

The relative high and significant correlation between $\mathrm{CH}_{4}$ uptake and WSOC indicates that the decreased soil C might have increased $\mathrm{CH}_{4}$ diffusion into the soil profile. Removal of the $\mathrm{C}$ rich $\mathrm{O}$ horizon caused by the prescribed burning eliminated a barrier for $\mathrm{CH}_{4}$ diffusion. This is also supported by the decreasing $\mathrm{CH}_{4}$ uptake and recovered WSOC in November 2014, combined with recovered litter deposit and ground plant regrowth. This effect of prescribed burning reduced thickness of organic layer to $\mathrm{CH}_{4}$ uptake was also found in similar forest ecosystems (Saari et al., 1998; Steinkamp et al., 2001). Another possible reason for the observed characteristics of $\mathrm{CH}_{4}$ uptake is the physical changes in the surface soil. Although not measured in the current study, the literature has shown that low to moderate fires 
would increase soil structure stability due to the formation of the hydrophobic film on the external surface of aggregates (Mataix-Solera and Doerr, 2004). With a lack of protection of ground plants and litter layers, surface soil was more likely to lose more fine fractions and lead to soil coarsening by the increased erosion (Certini, 2005). These physical changes in the surface soil would all form channels ideal for diffusion of atmosphere $\mathrm{CH}_{4}$ into the soil profile and thereby increase $\mathrm{CH}_{4}$ oxidation rates.

\subsection{2 $\mathrm{CO}_{2}$ effluxes}

The studied plots acted as a persistent source of atmospheric $\mathrm{CO}_{2}$ before and after the prescribed burning, while the $\mathrm{CO}_{2}$ emission rates, either before or after the burning, were similar to the results obtained by Carlyle and Than (1988) in a native forest with low soil moisture (about $5520 \mathrm{mg} \mathrm{m}^{-2} \mathrm{~d}^{-1}$ ) and by Rowlings et al. (2012) in an Australian subtropical rainforest (around $3600 \mathrm{mg} \mathrm{m}^{-2} \mathrm{~d}^{-1}$ ). However, the $\mathrm{CO}_{2}$ emission values were much lower than the reported high soil respirations (over $20000 \mathrm{mg} \mathrm{m}^{-2} \mathrm{~d}^{-1}$ ) in various Australian forest ecosystems with high soil moisture and temperature (Carlyle and Than, 1988; Fest et al., 2009; Rowlings et al., 2012). A number of studies have reported reduced $\mathrm{CO}_{2}$ emissions after the fire due to diminished root activity and lower root respirations (Czimczik et al., 2006; Kim et al., 2011; Sullivan et al., 2011), and the effects would last for various lengths from less than 2 years (Weber, 1990; Irvine et al., 2007) to longer periods (Burke et al., 1997). However, in this study, it seems that $\mathrm{CO}_{2}$ emission started recovering 3 months after the burning. This is supported by the similar $\mathrm{CO}_{2}$ emission rates in August $2014(p=0.218)$ and November 2014 ( $p=0.549$ ) between the burned and adjacent unburned plots. The decreased $\mathrm{CO}_{2}$ flux 3 months after the burning, which is only $41 \%$ of that before burning, might be attributed to the reduced root respiration and decomposition activities related to soil microbial communities. The observed high HWEOC value in August 2014 probably indicated increased dead fine roots after the combustion of ground biomass, which was in agreement with the estimation that after removing the aboveground biomass, most fine roots would die within 2 months by Fahey and Arthur (1994). Meanwhile, studies have reported that root respiration could contribute up to $50 \%$ of the total soil respiration (Irvine and Law, 2002; Zerva and Mencuccini, 2005). Decomposition of the dead fine roots could lead to the flush of $\mathrm{C}$ substrate but this was limited by the decreased microbial activities in this study, suggested by the significant lower MBC and MBN values in August and November 2014. Meanwhile, lower MBC in the burned plots compared to the unburned plots probably also suggested a reduced heterotrophic contribution to total soil respiration. A similar finding was also reported by Sullivan et al. (2011) who concluded that $\mathrm{MBC}$ explained a large proportion of the variation in soil $\mathrm{CO}_{2}$ flux at the burned site than at the unburned sites in a ponderosa forest in south-western USA.
Considering the positive relationship between $\mathrm{CO}_{2}$ efflux and WSOC, which was an important part of soil labile $\mathrm{C}$, microbial biomass was likely to be limited by the amount of labile $\mathrm{C}$ available for assimilation into microbial biomass. Maheswaran and Attiwill (1989) and Zerva and Mencuccini (2005) also reported reduced $\mathrm{CO}_{2}$ emission which was related to reduced microbial populations limited by an available source of $\mathrm{C}$ after the fire. Such an explanation can be further supported by the subsequent recovery of $\mathrm{CO}_{2}$ flux 6 months after the burning, combined with recovered MBC to the near pre-burning level and higher WSOC levels than before the burning. It was also reasonable that higher temperature in November 2014 had stimulated the surface soil respiration and therefore could contribute to the higher $\mathrm{CO}_{2}$ emission rate.

\subsection{3 $\quad \mathrm{N}_{2} \mathrm{O}$ emissions}

The soil-atmosphere fluxes of $\mathrm{N}_{2} \mathrm{O}$ measured in the study were very small $\left(-0.21-0.54 \mathrm{mg} \mathrm{m}^{-2} \mathrm{~d}^{-1}\right.$ before the burning and $-0.18-0.11 \mathrm{mg} \mathrm{m}^{-2} \mathrm{~d}^{-1}$ after the burning). These low fluxes were similar to the small $\mathrm{N}_{2} \mathrm{O}$ emission reported by Fest et al. (2009) and Livesley et al. (2011), but was much lower than the range of $0.75-8.19 \mathrm{mg} \mathrm{m}^{-2} \mathrm{~d}^{-1}$ recorded by Kiese et al. (2003) in a tropical rainforest and the range of $0.62-1.57 \mathrm{mg} \mathrm{m}^{-2} \mathrm{~d}^{-1}$ by Rowlings et al. (2012) in a subtropical rainforest. No significant effect of prescribed burning was observed on the $\mathrm{N}_{2} \mathrm{O}$ emission. Since forest soils were generally accepted as a source of atmospheric $\mathrm{N}_{2} \mathrm{O}$ (Butterbach-Bahl et al., 1997), the negative values we measured might be attributed to the low changes in $\mathrm{N} 2 \mathrm{O}$ concentration during the chamber employment, and these changes were below the detection limit of the GC system. Even though the dry and well aerated soil of the sampled plots would make it prone to nitrification rather than denitrification, the observed small inorganic $\mathrm{N}$ pool $\left(\mathrm{NH}_{4}^{+}<\right.$than $10 \mathrm{mg} \mathrm{N} \mathrm{kg}^{-1}$ while $\mathrm{NO}_{3}^{-}<0.1 \mathrm{mg} \mathrm{N} \mathrm{kg}^{-1}$ ) dominated by $\mathrm{NH}_{4}^{+}$also limited the nitrification processes. Although there was a significant increase in $\mathrm{NH}_{4}^{+} 3$ months $(p=0.009)$ and 6 months ( $p=0.009$ ) after the burning, nitrification was still negligible. This could be attributed to low soil water availability and dry conditions after prescribed burning, since the removal of understory plants and litter layers and increased evapotranspiration rates would limit the activities of soil nitrifiers (Livesley et al., 2011). Also the prescribed burninginduced charcoal at the soil surface which would also suppress $\mathrm{N}_{2} \mathrm{O}$ exchange rates as reported in a recent controlled experiment in Japan (Kim et al., 2011). However, accumulated $\mathrm{N}$ substrate, either $\mathrm{NH}_{4}^{+}$or $\mathrm{NO}_{3}^{-}$, might cause further high $\mathrm{N}_{2} \mathrm{O}$ emissions under appropriate conditions, for example, submerged soil after precipitations. 


\subsection{Contribution of the gas emissions to the burning introduced greenhouse gas effect}

Although consistently consuming atmospheric $\mathrm{CH}_{4}$, the forest soil in Toohey Forest still acted as a net $\mathrm{C}$ source to the atmosphere, due to the greater $\mathrm{CO}_{2}$ emission rates during the studied period. However, the burning-induced lower $\mathrm{CO}_{2}$ emission and higher $\mathrm{CH}_{4}$ uptake rates could significantly reduce the amount of $\mathrm{C}$ released into atmosphere, especially when extending these effects to the first several months after the burning. This reduced $\mathrm{C}$ emission could partly compensate the greenhouse gas effect during the operation of the burning: prescribed burning could cause eruption of $\mathrm{CO}_{2}$ into the atmosphere by combusting photosynthetic fixed $\mathrm{C}$ embedded in understory plants, litter layers, surface soil organic $\mathrm{C}$ and also the consumption of fossil fuels. Data on the $\mathrm{C}$ loss due to prescribed burning, fuel consumed and continuous measurement of soil gas exchanges are required to quantify the burning-induced greenhouse effect in future studies.

\section{Conclusions}

The low-intensity prescribed burning in Toohey Forest caused changes in both soil properties and greenhouse gas exchange rates. Soil $\mathrm{CH}_{4}$ uptake was significantly enhanced due to the increased $\mathrm{CH}_{4}$ diffusivity into the soil profiles. The removal of litter layer and surface soil organic materials and the altered soil physical structural caused by the prescribed burning were the major factors contributing to the increased $\mathrm{CH}_{4}$ diffusion. The $\mathrm{CO}_{2}$ emission was largely decreased but it was largely caused by natural annual variations. Changes in root respiration and soil microbial community were the two controlling factors related to the effect of prescribed burning on $\mathrm{CO}_{2}$ emission. Due to the controlled condition of prescribed burning, both $\mathrm{CH}_{4}$ uptake and $\mathrm{CO}_{2}$ emission started to recover about 3 months after the burning and it would appear that the gas exchange rates were recovered to the preburning level about 6 months after the burning. This rapid recovery was closely related to the limited effect of prescribed burning on the soil. However, the decreased $\mathrm{CO}_{2}$ emission and increased $\mathrm{CH}_{4}$ uptake during this period could still partly compensate the greenhouse gas effect caused by the combustion of $\mathrm{C}$ during the burning. The $\mathrm{N}_{2} \mathrm{O}$ emission was quite low in the studied plots and showed no obvious impacts of prescribed burning.

Acknowledgements. This work was sponsored by grants from the Australian Research Council. We acknowledge Geoffrey Lambert, Rongxiao Che, Iman Tahmasbian, and Mone Nouansyvong for their assistance in the field work. We also thank Geoffrey Lambert, Zhongming Lan, Haibo Dong, and Carolyn Polson for their technical supports in sample analysis.

Edited by: Z. Jia

\section{References}

Arocena, J. M. and Opio, C.: Prescribed fire-induced changes in properties of sub-boreal forest soils, Geoderma, 113, 1-16, 2003.

Bai, H. S., Sun, F., Xu, Z., Blumfield, T., Chen, C., and Wild, C.: Appraisal of ${ }^{15} \mathrm{~N}$ enrichment and ${ }^{15} \mathrm{~N}$ natural abundance methods for estimating $\mathrm{N}_{2}$ fixation by understorey Acacia leiocalyx and A. disparimma in a native forest of subtropical Australia, J. Soils Sediments, 12, 653-662, 2012.

Brookes, P. C., Landman, A., Pruden, G., and Jenkinson, D. S.: Chloroform fumigation and the release of soil nitrogen: a rapid direct extraction method to measure microbial biomass nitrogen in soil., Soil Biol. Biochem., 17, 837-842, 1985.

Burke, R. A., Zepp, R. G., Tarr, M. A., Miller, W. L., and Stocks, B. J.: Effect of fire on soil-atmosphere exchange of methane and carbon dioxide in Canadian boreal forest sites, J. Geophys. Res.Atmos., 102, 29289-29300, 1997.

Butterbach-Bahl, K., Gasche, R., Breuer, L., and Papen, H.: Fluxes of $\mathrm{NO}$ and $\mathrm{N}_{2} \mathrm{O}$ from temperate forest soils: Impact of forest type, $\mathrm{N}$ deposition and of liming on the $\mathrm{NO}$ and $\mathrm{N}_{2} \mathrm{O}$ emissions, Nutr. Cycl. Agroecosys., 48, 79-90, 1997.

Carlyle, J. C. and Than, U. B.: Abiotic controls of soil respiration beneath an eighteen-year-old pinus radiata stand in south-eastern Australia, J. Ecol., 76, 654-662, 1988.

Castro, M. S., Melillo, J. M., Steudler, P. A., and Chapman, J. W.: Soil moisture as a predictor of methane uptake by temperate forest soils, Can. J. Forest Res., 24, 1805-1810, 1994.

Catterall, C. P. and Wallace, C. J.: An Island in Suburbia: the Natural and Social History of Toohey Forest, Institute of Applied Environmental Research, Griffith University, Brisbane, 1987.

Catterall, C. P., Piper, S. D., Bunn, S. E., and Arthur, J. M.: Flora and fauna assemblages vary with local topography in a subtropical eucalypt forest, Austral. Ecol., 26, 56-69, 2001.

Certini, G.: Effects of fire on properties of forest soils: a review, Oecologia, 143, 1-10, 2005.

Covington, W. W. and Sackett, S. S.: Soil mineral nitrogen changes following prescribed burning in ponderosa pine, Forest. Ecol. Manage., 54, 175-191, 1992.

Czimczik, C. I., Trumbore, S. E., Carbone, M. S., and Winston, G. C.: Changing sources of soil respiration with time since fire in a boreal forest, Glob. Change Biol., 12, 957-971, 2006.

Dalal, R. C., Wang, W., Robertson, G. P., and Parton, W. J.: Nitrous oxide emission from Australian agricultural lands and mitigation options: a review, Aust. J. Soil Res., 41, 165-195, 2003.

Diaz-Raviña, M., Prieto, A., Acea, M. J., and Carballas, T.: Fumigation-extraction method to estimate microbial biomass in heated soils, Soil Biol. Biochem., 24, 259-264, 1992.

Fahey, T. J. and Arthur, M. A.: Further-studies of root decomposition following harvest of a northern hardwoods forest, For. Sci., 40, 618-629, 1994.

Farmer, D., Catterall, C. P., and Piper, S. D.: Abundance patterns across months and locations, and their differences between migrant and resident landbirds in lowland subtropical eucalypt forest, Emu, 104, 283-296, 2004.

Fest, B.: The impact of fire disturbance and simulated climate change conditions on soil methane exchange in eucalypt forests of south-eastern Australia, Department of Forest and Ecosystem Science, Melbourne School of Land and Environment, University of Melbourne, 2013. 
Fest, B. J., Livesley, S. J., Drösler, M., van Gorsel, E., and Arndt, S. K.: Soil-atmosphere greenhouse gas exchange in a cool, temperate Eucalyptus delegatensis forest in south-eastern Australia, Agr. Forest Meteorol., 149, 393-406, 2009.

Fest, B. J., Livesley, S. J., Fischer, J. C., and Arnadt, S. K.: Repeated fuel reduction burns have little long-term impact on soil greenhouse gas exchange in a dry sclerophyll eucalypt forest, Agr. Forest Meteorol., 201, 17-25, 2015.

Fu, L., Zhao, Y., Xu, Z. H., and Wu, B. F.: spatial and temporal dynamics of forest aboveground carbon stocks in rsponse to climate and environmental changes, J. Soils Sediments, 15, 249$259,2015$.

Granged, A. J. P., Jordán, A., Zavala, L. M., Muñoz-Rojas, M., and Mataix-Solera, J.: Short-term effects of experimental fire for a soil under eucalyptus forest (SE Australia), Geoderma, 167/168, 125-134, 2011.

Guinto, D. F., Xu, Z. H., Saffigna, P. G., House, A. P. N., and Perera, M. C. S.: Soil nitrogen mineralisation and organic matter composition revealed by ${ }^{13} \mathrm{C}$ NMR spectroscopy under repeated prescribed burning in eucalypt forests of south-east Queensland, Aust. J. Soil Res., 37, 123-136, 1999.

Guinto, D. F., Xu, Z., House, A. P. N., and Saffigna, P. G.: Assessment of $\mathrm{N}_{2}$ fixation by understorey acacias in recurrently burnt eucalypt forests of subtropical Australia using ${ }^{15} \mathrm{~N}$ isotope dilution techniques, Can. J. Forest. Res., 30, 112-121, 2000.

Hernández, T., García, C., and Reinhardt, I.: Short-term effect of wildfire on the chemical, biochemical and microbiological properties of Mediterranean pine forest soils, Biol. Fert. Soils, 25, 109-116, 1997.

Irvine, J. and Law, B. E.: Contrasting soil respiration in young and old-growth ponderosa pine forests, Glob. Change Biol., 8, 11831194, 2002.

Irvine, J., Law, B. E., and Hibbard, K. A.: Postfire carbon pools and fluxes in semiarid ponderosa pine in Central Oregon, Glob. Change Biol., 13, 1748-1760, 2007.

Jaatinen, K., Knief, C., Dunfield, P. F., Yrjålå, K., and Fritze, H.: Methanotrophic bacteria in boreal forest soil after fire, FEMS Microbiol. Ecol., 50, 195-202, 2004.

Kiese, R. and Butterbach-Bahl, K.: $\mathrm{N}_{2} \mathrm{O}$ and $\mathrm{CO}_{2}$ emissions from three different tropical forest sites in the wet tropics of Queensland, Australia, Soil Biol. Biochem., 34, 975-987, 2002.

Kiese, R., Hewett, B., Graham, A., and Butterbach-Bahl, K.: Seasonal variability of $\mathrm{N}_{2} \mathrm{O}$ emissions and $\mathrm{CH}_{4}$ uptake by tropical rainforest soils of Queensland, Australia, Glob Biogeochem. Cy., 17, doi:10.1029/2002GB002014, 2003.

Kim, Y. S., Makoto, K., Takakai, F., Shibata, H., Satomura, T., Takagi, K., Hatano, R., and Koike, T.: Greenhouse gas emissions after a prescribed fire in white birch-dwarf bamboo stands in northern Japan, focusing on the role of charcoal, Eur. J. Forest Res., 130, 1031-1044, 2011.

Knoepp, J. D. and Swank, W. T.: Site preparation burning to improve southern Appalachian pine-hardwood stands: nitrogen responses in soil, soil water, and streams, Can. J. Forest Res., 23, 2263-2270, 1993.

Lennon, J. T.: Replicatoin, lies and lesser-known truths regardsing experimental design in environmental microbiology, Environ. Microbiol., 13, 1383-1386, 2011.

Livesley, S. J., Grover, S., Hutley, L. B., Jamali, H., ButterbachBahl, K., Fest, B., Beringer, J., and Arndt, S. K.: Seasonal varia- tion and fire effects on $\mathrm{CH}_{4}, \mathrm{~N}_{2} \mathrm{O}$ and $\mathrm{CO}_{2}$ exchange in savanna soils of northern Australia, Agr. Forest Meteorol., 151, 14401452, 2011.

Maheswaran, J. and Attiwill, P. M.: Soil respiration in eucalypt forests of southeastern Australia, Biol. Fert. Soils 8, 154-159, 1989.

Mataix-Solera, J. and Doerr, S. H.: Hydrophobicity and aggregate stability in calcareous topsoils from fire-affected pine forests in southeastern Spain, Geoderma, 118, 77-88, 2004.

Murphy, B. F. and Timbal, B.: A review of recent climate variability and climate change in southeastern Australia, Int. J. Climatol., 28, 859-879, 2008.

Nardoto, G. B. and Bustamante, M. M. C.: Effects of fire on soil nitrogen dynamics and microbial biomass in savannas of Central Brazil, Pesqui. Agropecu. Bras., 38, 955-962, 2003.

Nave, L. E., Vance, E. D., Swanston, C. W., and Curtis, P. S.: Fire effects on temperate forest soil $\mathrm{C}$ and $\mathrm{N}$ storage, Ecol. Appl., 21, 1189-1201, 2011.

Neary, D. G., Klopatek, C. C., DeBano, L. F., and Ffolliott, P. F. Fire effects on belowground sustainability: a review and synthesis, Forest. Ecol. Manage., 122, 51-71, 1999.

Ponder Jr., F., Tadros, M., and Loewenstein, E. F.: Microbial properties and litter and soil nutrients after two prescribed fires in developing savannas in an upland Missouri Ozark Forest, Forest Ecol. Manage., 257, 755-763, 2009.

Prieto-Fernández, A., Acea, M. J., and Carballas, T.: Soil microbial and extractable $\mathrm{C}$ and $\mathrm{N}$ after wildfire, Biol. Fert. Soils, 27, 132$142,1998$.

Prosser, J. I.: Replicate or lie, Environ. Microbiol., 12, 1806-1810, 2010.

Rhoades, C. C., Meier, A. J., and Rebertus, A. J.: Soil properties in fire-consumed log burnout openings in a Missouri oak savanna, Forest. Ecol. Manage., 192, 277-284, 2004.

Rowlings, D. W., Grace, P. R., Kiese, R., and Weier, K. L.: Environmental factors controlling temporal and spatial variability in the soil-atmosphere exchange of $\mathrm{CO}_{2}, \mathrm{CH}_{4}$ and $\mathrm{N}_{2} \mathrm{O}$ from an Australian subtropical rainforest, Glob. Change Biol, 18, 726-738, 2012.

Saari, A., Heiskanen, J., and Martikainen, P. J.: Effect of the organic horizon on methane oxidation and uptake in soil of a boreal Scots pine forest, FEMS Microbiol. Ecol., 26, 245-255, 1998.

Seidl, R., Schelhaas, M.-J., Rammer, W., and Verkerk, P. J.: Increasing forest disturbances in Europe and their impact on carbon storage, Nat. Clim. Change, 4, 806-810, 2014.

Sherwood, S. and Fu, Q.: A Drier Future?, Science, 343, 737-739, 2014.

Sommerfeld, R. A., Mosier, A. R., and Musselman, R. C.: $\mathrm{CO}_{2}$, $\mathrm{CH}_{4}$ and $\mathrm{N}_{2} \mathrm{O}$ flux through a Wyoming snowpack and implications for global budgets, Nature, 361, 140-142, 1993.

Steinkamp, R., Butterbach-Bahl, K., and Papen, H.: Methane oxidation by soils of an $\mathrm{N}$ limited and $\mathrm{N}$ fertilized spruce forest in the Black Forest, Germany, Soil Biol. Biochem., 33, 145-153, 2001.

Sullivan, B. W., Kolb, T. E., Hart, S. C., Kaye, J. P., Hungate, B. A., Dore, S., and Montes-Helu, M.: Wildfire reduces carbon dioxide efflux and increases methane uptake in ponderosa pine forest soils of the southwestern USA, Biogeochemistry, 104, 251-265, 2011. 
Vance, E. D., Brookes, P. C., and Jenkinson, D. S.: An extraction method for measuring soil microbial biomass C, Soil Biol. Biochem., 19, 703-707, 1987.

Wan, S., Hui, D., and Luo, Y.: Fire effects on nitrogen pools and dynamics in terrestrial ecosystems: a meta-analysis, Ecol. Appl., 11, 1349-1365, 2001.

Wang, Y., Xu, Z., and Zhou, Q.: Impact of fire on soil gross nitrogen transformations in forest ecosystems, J. Soils Sediments, 14, 1030-1040, 2014.

Wang, Y., Xu, Z., Zheng, J., Abdullah, K., and Zhou, Q.: $\delta^{15} \mathrm{~N}$ of soil nitrogen pools and their dynamics under decomposing leaf litters in a suburban native forest subject to repeated prescribed burning in southeast Queensland, Australia, J. Soils Sediments, 15, 1063-1074, 2015.
Weber, M. G.: Forest soil respiration after cutting and burning in immature aspen ecosystems, Forest Ecol. Manage., 31, 1-14, 1990.

Xue, L., Li, Q., and Chen, H.: Effects of a wildfire on selected physical, chemical and biochemical soil properties in a pinus massoniana forest in south China, Forests, 5, 2947-2966, 2014.

Zerva, A. and Mencuccini, M.: Short-term effects of clearfelling on soil $\mathrm{CO}_{2}, \mathrm{CH}_{4}$, and $\mathrm{N}_{2} \mathrm{O}$ fluxes in a Sitka spruce plantation, Soil Biol. Biochem., 37, 2025-2036, 2005. 